\title{
We Are Woke: A Collaborative Critical Autoethnography of Three "Womxn" of Color Graduate Students in Higher Education
}

\author{
Aeriel A. Ashlee \\ Miami University \\ U. S. A. \\ Bianca Zamora \\ Miami University \\ U. S. A. \\ Shamika N. Karikari \\ Miami University \\ U. S. A.
}

ABSTRACT: This critical collaborative autoethnography examines how three "womxn" of color (Asian American, Latina, and African American) graduate students experience and resist intersectional racism and sexism in higher education. The authors reflect on their individual journeys to "wokeness" and share their collective process of cultivating a community of "sista" scholars integral to their wellness, wokeness, and persistence in an oppressive educational system.

KEYWORDS: women of color, intersectionality, critical race theory, woke, higher education

\author{
Why We Write \\ Our Stories \\ Wokeness Revealed \\ Notes \\ References \\ Author Contact
}

To be woke

is not just a political ideology,

It is an unretractable existence

A contradictory remedy of healing and pain.

The cultivation of a deep and necessary consciousness of survival

that slices white patriarchal supremacy

and wounds the heart-opening minds.

Our eyes never shut. Our voices never seize.

We are courageous, we are fierce, we are exhausted.

And yet we persist. We are Alive. We are here.

We are WOKE. 


\section{Why We Write}

The opening co-authored poem represents our collective agency and solidarity as we exist and resist within a racist and sexist educational system. While our racial identities differ, as an Asian American, Latina, and African American respectively, we formed--out of necessity--a powerful wom $\mathrm{xn}^{1}$ of color sista scholar ${ }^{2}$ familia. As graduate students who began our studies at the same time, in the same program, at the same predominantly white ${ }^{3}$ institution in the rural Midwest, we gravitated to one another for survival.

We write together because we want to honor each other. We write together to reflect on the incredible power that our sista scholar familia has revealed and we have individually and collectively. We write together to reach out to other womxn of color graduate students to assure them that they are not alone, to validate their presence, and to encourage their persistence. This paper is about process: our reflective and liberating process as womxn of color graduate students to resist the intersectional oppression of the ivory tower by asserting our collective journey of wokeness. By authoring our stories, we seek to inspire other sista scholars, to give voice to their truths, to build community with one another, and to reject the toxicity of dominance and oppression inherent in the academy.

We use intersectionality as an interpretative framework to address the oppression we experience as womxn of color, as our race and gender inform each other and are interwoven. Crenshaw (1991) coined the term intersectionality to describe "the location of wom[x]n of color both within overlapping systems of subordination and at the margins of feminism and antiracism" (p. 1265). Crenshaw's conceptualization of intersectionality emerged from legal studies and has since been applied to other disciplines including the field of education (Ladson-Billings, 1998). Applying Crenshaw's term to our experiences as woke womxn of color graduate students enables us to more deeply understand the interplay of racism and sexism within the academy.

We define wokeness as critical consciousness to intersecting systems of oppression. Specifically, to be a woke person is to hold an unretractable embodied consciousness and political identity acknowledging the oppression that exists in individual and collective experiences. As womxn of color with hxrstories ${ }^{4}$ of colonization, our oppressors work to keep us blinded, silenced, and complacent with inequities of power by claiming a post-racist and post-sexist America. We argue that for womxn of color to be woke is to hold capital against an oppressive system by articulating the system's existence. A woke womxn does not have to possess the language to name oppression, but rather know of oppression and reject its unjust nature.

We connect wokeness to the articulations of critical consciousness and standpoint epistemologies by womxn of color feminist scholars. Asserting one's feminist standpoint calls for a process of critical consciousness to systems of domination and serves as claim to agency and cognitive liberation (Anzaldúa, 1987; Collins, 2000; Lorde, 1984; Souto-Manning \& Ray, 2007). Building upon Collins' (2000) concept of the 
"outsiders within" (p. 11), as womxn of color in higher education we have a specialized and yet often discounted perspective informed by our experience occupying the margins of the academy. Similar to how some womxn may claim a political identity as feminists, we claim a political identity as woke womxn of color. For example, "Chicana feminisms constitute a political stance that confronts and undermines patriarchy as it crosscuts forms of disempowerment and silencing such as racism, homophobia, class inequity, and nationalism" (Arredondo, Hurtado, Klahn, Najera-Ramirez, \& Zavella, 2003, p. 2). Maria Stewart (as cited in Loewenberg \& Bogin, 1976) declares, "O, ye daughters of Africa, Awake! No longer sleep nor slumber, but distinguish yourselves. Show forth to the world that ye are endowed with noble and exalted faculties" (p. 187). We too call for an epistemological and spiritual decolonization by articulating the criticality of a community of woke womxn of color sista scholars. We honor past and present womxn of color feminist ideologies by proposing a political and personal identity that unites womxn of color who feel and articulate their experiences of oppression.

We utilize critical collaborative autoethnography as an act of resistance. Collaborative autoethnography as a process empowers researchers to engage in a collective examination of individual autobiographies to understand a sociocultural phenomenon (Chang, Ngunjiri, \& Hernandez, 2013). "The term critical collaborative ethnography further refers to a practice of ethnography that is invested in questioning the boundaries of power relations between the researcher and the researched for the specific purpose of bringing about social change" (Bhattacharya, 2008, p. 306). We situate our research in a critical paradigm (Brookfield, 2005; Ladson-Billings, 1998) to collectively examine our experiences of intersectional oppression. We hope to disrupt the pattern of isolation experienced by womxn of color in higher education as we draw from critical theories to collectively "search for an understanding of others (culture/society) through the self" (Chang, 2009, p. 40). Therefore, autoethnography enables us to consider ourselves in relation to the recycled discourses of oppression in the academy with the goal of liberation for ourselves and future womxn of color in higher education.

Collaborative critical autoethnography is thus not only a methodological approach to qualitative inquiry, but also a form of empowerment that facilitates survival, solidarity, and resilience as we examine wokeness. By authoring our counterstories through this process, we destabilize the hegemonic assumptions of a male-dominated, white supremacist institution, namely higher education. Our process of vulnerably sharing our stories of wokeness and identifying common themes across our experiences is collaborative autoethnographic research in action. As such, this paper is a form of critical activism that challenges and destabilizes racist and patriarchal educational practices. We hope that our writing will empower criticality and spur a community of support for womxn of color graduate students in higher education.

In this paper, we provide brief narratives of our individual journeys of wokeness in graduate school to contextualize our respective stories within a system of oppression. Next, we describe our collective data analysis, through which we identified three themes vital to our wokeness: (1) the agent of wokeness, (2) the duality of wokeness, and (3) community as a necessity to staying woke. We conclude our paper by calling for a movement that unites womxn of color across racial lines to cultivate and sustain our 
wokeness, well-being, and power.

\section{Our Stories}

For this project, we wanted to more deeply understand our common experiences as woke womxn of color graduate students. Our close bond as a sista scholar familia serves as the relational foundation that enables us to authentically and vulnerably share our most intimate reflections on becoming and staying woke. To begin our collaborative autoethnographic process, each co-author independently wrote a personal vignette reflecting on wokeness. We responded in our own creative form to the following prompts:

1. Share an experience you have had with intersectional oppression centering race and gender during graduate school.

2. What does it mean to be woke? Share an example in graduate school when you were woke, or which helped you become more woke.

3. Share an isolating experience you have had in graduate school.

The following are excerpts from our independently authored first-person narratives. We include these portions of our stories as insight into our epistemological process of wokeness.

\section{Aeriel's Story}

In the spring of 2016, I took to Twitter to make public my commitment to dismantling white supremacy. As a transracial Asian American adoptee, as a womxn of color, and as a critical race scholar-activist, I felt compelled to express my exhaustion and frustration with repeated demonstrations of white dominance by well-intended, selfproclaimed, anti-racist allies. Unfortunately, asserting my wokeness in this way resulted in my being targeted with horrific racist, sexist, xenophobic, anti-adoption hate via social media. Instead of disagreeing with or challenging my ideas, trolls from across the Internet used my oppressed identities to attack my very personhood through threats of violence. While I quickly familiarized myself with the block function on Twitter, the pain and fear associated with living and speaking out against racism was made real in a traumatic way. In search of strength, I turned to woke womxn of color sista scholar, Dr. Cheryl Matias, who wrote, "Amidst this constant aggressive attack to colonize our identities, we survive. We endure" (2015, p. 61). These words enabled me to acknowledge the realities of racial battle fatigue and find the capacity to persevere in my wokeness and resistance.

The brutality I experienced in the Twitterverse deeply affected my personal wellness and academic performance. Daily encounters that previously felt like small acts of resistance, such as walking with my head held high through the hallways of my academic building or across campus at the rural and predominantly white institution where I am pursuing my doctoral studies, now feel daunting and unsafe. I must manage 
this heightened isolation while also combating an angry mob of online dissenters who have taken to attacking me and my identities because they disagree with my ideas. The salt to my wounds is knowing that my white-male counterparts in academia do not have to endure this kind of treatment (Matias, 2015; Mohamed, 2010; Nast, 1999; Pittman, 2010; Souto-Manning \& Ray, 2007; Williams, Dunlap, \& McCandies, 1999). As it turns out, there is a special kind of hate reserved specifically for those of us whose very existence challenges the status quo. Feeling on the verge of defeat, Matias' (2015) description of how she persists despite her oppressors' best efforts is the anthem of hope I desperately need to hear.

Like Matias, as a womxn of color in academia, I must not only survive the compounding trauma of racism and sexism in the academy, but should I ever choose to boldly and publicly resist my oppressors, I run the risk of being subjected to further hate and humiliation. This is a whole new arena of wokeness to which, ironically, I am just awakening. Up to this point in my life, being woke has meant cultivating a critical awareness of privilege and oppression and doing whatever is in my capacity to dismantle those forces. Perhaps naively, I previously thought of being woke as hard, but not dangerous. However, the outlash of violence in response to my using Twitter to assert my wokeness has alerted me to the real risks involved. As exhausted as I am, I remain encouraged to know that there are fierce sista scholars like Matias and Bianca and Shamika, my coauthors, who are committed to being woke and staying woke.

\section{Bianca's Story}

I have become too familiar with the ritualized game of being a woke Latina in white dominated institutions (WDI). Having experienced racism as an undergraduate at a WDI in California, I arrogantly believed I was prepared for the intensity of graduate studies in rural Ohio. I was wrong. In graduate school, my experiences with oppression overwhelmingly increased. As a result, my wokeness, armor, and strategies for survival intensified.

It has been three weeks since the completion of my first year as a graduate student. My body is experiencing not only a spiritual cleansing, but a positive physical reaction to the reprieve from white academia and its oppressors. The sun seeps into my espíritu and I feel the toxicity of two semesters begin to melt from my shoulders. I am healing in a town where confederate flags fly through skies and come in the forms of bumper stickers, hanging car dice, and t-shirts worn by white men. Validation from my feminista bible, This Bridge Called My Back, woke sista scholars, and my own writings serve as ammunition for wokeness where the air is not mine to claim. Feminista goddess, Gloria Anzaldúa (1983), reminds me, "A wom[x]n who writes has power and a wom[x]n with power is feared" (p.164). The following are reflections from journals I wrote during my first year of graduate school.

It has been two weeks since my arrival to this racist and sexist town. I am wholeheartedly exhausted. I retreat to the deserted hot tub area at my apartment complex. Six white men and two white women enter the jacuzzi--among them is my 
white undergraduate roommate who for two weeks yells a stereotypical "ay ya yaaaaaay" and "Arriba, Arriba," whenever she sees me. My heart races as oppressors enter my momentary sacred space. A white man asks, "What are you?" I respond, "Latina". He screams, "beaner!" Everyone in the pool laughs. For three hours, these university students fire oppressive and colonizing words including, "Yeah, I dated a Mexican girl once." Two days later, I am studying at two o'clock in the morning when a white man approaches me. "Hey, what are you?" In a tired daze, I sigh, "Mexican." He responds, "Yeah, I dated a Mexican." \#ExhaustedBrownWomxn (Author's personal journal, September 19, 2015)

It is the second month of graduate school and I am sitting in my Foundations of Higher Education class. White womxn are sobbing. I glance up and give them an annoyed mirada and continue typing because ya no aguanto racistas. White peer colonizadores cry every week, not for people of color, but for themselves. For two hours of the week their lives are disrupted with conversations on race. Two... hours! I want to say, "Imagine 24 hours of this...living as an intersectional other." Their white tears fixated by the racism and sexism they refuse to acknowledge within themselves. These colonizers feel uncomfortable with their power being questioned. They want to remain complacent in their supremacist ideologies. As a woke Latina womxn, when I have the capacity, I call them out on their... I am a graduate student. I am here to learn, not to stroke the egos of white colonizers. (Author's personal journal, November, 4, 2015)

In a colonizing institution, my well-being and agency are in constant tension with oppressors. I hold woke sista scholars and my journals close to my heart as they strengthen my armor in the journey for wokeness and healing.

\section{Shamika's Story}

"It's exhilarating to be alive in a time of awakening consciousness; it can also be confusing, disorienting, and painful." - Adrienne Rich

Once you are awakened, your eyes are forever open to your surroundings. The illusion disappears and you finally accept the light. Being introduced to Critical Race Theory (Delgado \& Stefancic, 2001) initiated my awakening. As an African American womxn, my schooling revealed to me that Black and Brown scholars were invisible in the academy. The scholarly works assigned in classes did not represent my community or resonate with me. This led me to the erroneous belief that I did not belong in the academy, despite being sold the dream that I was "graduate school material."

Poetry is the language of my soul. Hill (2014) discussed utilizing poetry as a means for students to express themselves and wrote, "By asking students to poetically express their thoughts about race, I was encouraging them to expose their trepidations about race and race discussion, while simultaneously imagining the possibilities of racial dialogue with vulnerability and candidness present." (p. 173). Awakened is my poetic expression. 


\author{
Awakened \\ Behind the shadows, \\ It came to light. \\ The voice that was hidden, \\ In plain sight. \\ Awakened from the tomb. \\ Arose from the dead. \\ The fire and thunder, \\ Came roaring ahead. \\ It did not feel possible. \\ Can this be real? \\ The experiences of my heart, \\ I could finally feel. \\ The voices that were masked, \\ For far too long. \\ Hidden beneath, \\ The beat of the song \\ My heart longed to sing, \\ In a voice so loud, \\ So that all could know, \\ I'm Black and I'm proud.
}

Awakened is about the experience of not seeing myself in the curriculum from kindergarten through college, and my pathway to becoming woke. My awakening began in the spring of 2014 when I enrolled in a seminar course on race and education through a Critical Race Theory (CRT) lens. A Black womxn taught the course, and 12 of the 15 students identified as students of color. This was the first time in my schooling experience that I was in the racial majority. It was both empowering and invigorating. It birthed in me a confidence that no other educational experience had ever provided me. The class and discussions about CRT energized and excited me. Two years later, a different seminar course on CRT fully opened my mind to the possibility that there could be space for me in the academy, while acknowledging the reality that I would have to create the space myself.

As I read authors such as Matias (2015) and Baszile (2011), I started to believe that I too could authentically show up as my Black and womxn self and still be a part of the academy. Baszile (2011) wrote honestly regarding the rage that traditionally had not been welcomed when discussing matters of race. She asserted, "In order not to get too caught up in reproducing the problems I want to tackle, I need to speak to and through the emotions that make teaching about race and racism both possible and impossible. In short, I need to un-objectively and unapologetically shoot straight from the hip" (pp. 12). This radical declaration to no longer hold her emotions in, but let them out, is empowering to womxn like myself because it inspires me to do the same. Baszile and Matias exemplify the power of including critical scholars in the curriculum, and demonstrate how their voices influence womxn of color and the way we make meaning 
of our experience in the academy. Centering voices of color and woke critical scholars in the curriculum is essential for the empowerment of womxn of color in graduate school and is necessary to dismantle the systems of oppression that womxn of color experience in the academy.

\section{Wokeness Revealed}

It is a stifling hot mid-June afternoon. We meet in our department's lounge to sift through our respective stories in search of themes that might reveal new insights about the process of getting woke and staying woke as womxn of color graduate students in higher education. We spent countless hours in this same suite last year. Yet it is only as of today, sitting huddled around a table in the lounge with our beloved sista scholar familia, that we feel for the first time as if this space is ours. Instead of keeping our voices to a low murmur so as not to disrupt others, instead of doubting our belonging as cis-female bodies of color, we exude a palpable energy and radiate a sense of ownership. Empowered by one another's presence and stories, we bravely speak up and take up space. This is radical. This is resistance. We have been socialized throughout our lives to minimize our presence and doubt our legitimate brilliance by remaining in the shadows of white male supremacy. Today is different. Together, we embody confidence as we listen, heal, and learn from one another. We laugh loudly and speak boldly. We honor and affirm each other's wokeness. This is what it means to get woke and stay woke.

After reading each other's stories, we came together to review and make meaning of the data collectively. Aware that critical autoethnography is about connecting interpersonal experiences to larger systems of power (Boylorn \& Orbe, 2013), we convened to explore connections between our personal accounts of wokeness and the structural realities of higher education institutions. Through our collective reflective analysis, we identified three themes that are pertinent to the future resistance and persistence of woke womxn of color graduate students in higher education: (a) the criticality of an agent of wokeness as a catalyst to getting and staying woke, (b) the duality of wokeness as both painful and healing, and (c) the necessity of finding and cultivating a community of sista scholars.

\section{The Agent of Wokeness}

The first theme of wokeness is related to what we call "the agent of wokeness," the catalytic factor that provokes critical consciousness. In sharing stories about what or who facilitated our respective awakenings, we found that our woke agents varied from being a contextual learning environment, a historical figure, and a literal person. For Shamika, her agent of wokeness was cumulative learning. In graduate school she encountered Critical Race Theory, which became the foundation of her awakening and gave voice to her story. Enrolling in a class taught by a Black womxn professor on race, 
ethnicity, and education, in which a majority of the students were students of color, was another factor in her becoming woke. The experience of being in the racial majority in an academic context was integral to her consciousness. She writes in her journal, "That class began to stir something in me."

In a journal entry from her first semester of graduate school, Bianca reflects on the importance of calling upon a historical activist as her agent of wokeness. In order to maintain and preserve her wokeness in a new and challenging academic context, Bianca writes,

Last week I purposefully brought in Audre Lorde's quote, "The master's tools will never dismantle the master's house" because it is aimed toward white feminists who use racist and classist tactics to invisibilize womxn of color experiences. I don't think that the white womxn in the class understand that our gendered experiences are racialized and the intense consequences this truly has. (Author's personal journal, October 1, 2015)

Exhausted and at a loss for how to engage authentically as a woke womxn of color, Bianca relied on the legacy and language of a hxrstorical woke womxn of color to stay woke. Aeriel's agent of wokeness was also a person, but rather than a notable hxrstorical activist as in Bianca's awakening, Aeriel's catalyst was a faculty member. She recalls,

As a womxn of color in academia, an environment that was neither built by or for me and my community, I have struggled to be my authentic self, to breathe fully, to claim my space and use my voice. That is until I met Dr. J. Through working with and learning from this brilliant, honest, critical scholar, I have experienced a powerful awakening. Dr. J fearlessly names the realities of white supremacy in education and reminds his students to center our humanity. (Author's personal journal, June 10, 2016)

As a Black male scholar, Dr. J's criticality and transgressive pedagogy enables him to inspire and activate Aeriel's racial wokeness. While their experiences as scholars of color differ by gender, Dr. J's maleness does not inherently impede his ability to serve as an agent of wokeness.

We share these stories of our wokeness to demonstrate that agents of wokeness can be amorphous, taking the shape of a person, place, or theory. It is therefore necessary for the future facilitation and preservation of wokeness to explore how a woke agent, regardless of form, facilitates becoming woke. Common across our experiences was that our agents of wokeness introduced us to critical theory and scholarship and encouraged us to cultivate our own voices as emerging woke womxn of color. For example, Aeriel writes, "[Dr. J] assigns readings from amazingly fierce womxn of color scholars, in which I have finally seen myself in the literature." Similarly, Shamika reflects, "As I read authors who write with such expertise, passion, and strength, I am reminded that my writing can be academic and still authentic to my experiences as a Black womxn."

The power of written words, seeing our experiences reflected in literature authored by other woke womxn scholars of color, is the catalytic commonality across 
our individual processes of becoming woke. The fierce sista scholars who came before us, including bell hooks (1994), Audre Lorde (1984), and Cheryl Matias (2015), incite and embolden our wokeness. By reading their critical writing, we locate our own woke voices. After a lifetime of indoctrination, socialization, and patriarchal, white supremacist conditioning, access to critical theory and scholarship is an essential component to any agent of wokeness' effectiveness. This realization is vitally important to the continued liberation and awakening of womxn of color graduate students.

\section{The Duality of Wokeness}

Once womxn of color are awakened by an agent of wokeness, we must prepare for the enduring and often exhausting tension of concurrently cherishing and detesting our wokeness. The second theme that emerged from our analysis of wokeness was the realization of wokeness as dualistic_both a defeating and empowering praxis of existence. Wokeness is protective like armor, in that our critical consciousness can serve as a tool for survival by providing the power to name and actively contest our lived realities of oppression. But also like armor, wokeness is heavy and eventually weighs us down, causing mental and physical fatigue. The duality of wokeness is that it can be both painful and healing.

Shamika reflects back on the pain of wokeness as she remembers an experience she had walking down a university street. During this particular afternoon on campus, racial slurs were yelled at her by three white men in a truck. She was initially shocked at this blatant form of racism. Although administrators wanted her to see this instance as an unfortunate isolated event, her wokeness knew this act was part of a larger system of white and patriarchal supremacy, in which her identity as a Black womxn was attacked. The pain of this racist act has permanently imprinted her heart and reminds her that wokeness hurts.

The wounds of these types of encounters fester as internalized shame and insecurity about our place in higher education, which in turn impacts our physical and emotional well-being. In Aeriel's story, she recalls how asserting her wokeness on Twitter opened her to a barrage of online threats, which deeply affected her mental and physical functionality as a graduate student. Acts that previously seemed manageable, such as navigating campus as one of only a few Asian faces, became overwhelming. Similarly exhausted with the rawness of her wokeness, Bianca writes,

Two weeks after the "beaner" incident, I felt I was being followed around by an older white man while I grocery-shopped. I tried to shake off my "paranoia." After convincing myself I was not being followed, I found myself calm in the makeup aisle. Suddenly, the white man comes up to me and tells me how he loved my "Brown hair, Brown skin, and body." For two weeks, I traveled directly to my home, school and work. I did not want to be in public. These experiences of racist misogyny affected my mental health and ability to focus on my school work and research. (Author's personal journal, June 1, 2016)

Conversely, wokeness can also be a source of strength, healing, and liberation. 
For instance, Bianca finds agency and empowerment in her wokeness. Being woke to the overt and covert racist and sexist conditions of the academy enables her to identify the source of her oppressive pain and to fight against it.

Naming my peer's racist and misogynistic ideology is a tactic of resistance I use in the academy. In my mind I referred to asleep white peers as "white guy [insert name]" or "white girl [insert name]" because of their extremely problematic whitecentered and sexist remarks made in the classroom. I was conscious of who sat where, who said what, and I read between colonizer's palabras and actions that worked to oppress womxn and men of color in my cohort. (Author's personal journal, June 1, 2016)

Shamika also expresses how her wokeness enables her to empower herself and others as legitimate producers of knowledge by rejecting the limitations of white-male-centered academia.

I continued to resist the notion that academic writing was only valued when it mirrored that of white scholars. I used my voice to write in the way I wanted. Resisting in this way gave me a little bit of power, but I still thought the academy would never be for me. That was until I found authors that spoke to my experience. Imagine how many more Brown and Black scholars would exist in the academy if they were exposed to scholars that looked like them early in education? How different the academy could be! (Author's personal journal, June 2, 2016)

For Aeriel, her wokeness served as the strength needed to create an independent study that explored the lives of Grace Lee Boggs and Yuri Kochiyama, two woke Asian American womxn of color. Through this self-designed learning, Aeriel found further empowerment in her journey of wokeness.

This semester, I set out to become an activist. For my entire career as a college advisor and administrator, I have been committed to and invested in social justice. However, I have primarily enacted this value through advising and educating others. The past few months have been my critical awakening. My radicalization. I am now the activist. (Author's personal journal, May 1, 2016)

While wokeness is essential to our liberation as womxn of color graduate students in higher education, we do not want to overly romanticize wokeness. To be woke is the antidote that enables healing from systems of oppression. And yet, in that healing we open our eyes and spirits to deep pain. Understanding this duality of wokeness is necessary to fully grasp the complexity of wokeness. To endure and stay woke, womxn of color must acknowledge the contradiction and conundrum of desiring the liberatory potential of critical consciousness while also shouldering the wrath and weight of wokeness.

\section{Community as a Necessity to Staying Woke}

To bear the burden of the duality of wokeness, community is necessary. In 
analyzing our stories and experiences as woke womxn of color graduate students, the centrality of our sista scholar community to our survival emerged as the third and perhaps most critical theme. Although we are each on our own journey of getting and staying woke, we recognize the collective need for solidarity. We acknowledge the importance of community because we each have experienced a lack thereof at multiple points during our academic careers. We each have instances where we yearned for people who got us: communities in which we saw ourselves and where we truly felt at home. However, because of our choice to occupy predominantly and hxrstorically white, male-dominated spaces like higher education, finding community at times is difficult. In a reflection, Aeriel explains, "Given my awareness that academia is inherently a white supremacist and male dominant field, I anticipated that my journey as an Asian American womxn of color in higher education may be one of solitude." This realization, albeit troubling, is an honest reminder of the ways womxn of color experience isolation when occupying spaces like the academy.

As the three of us sit in the department lounge discussing the notion of community together, something powerful happens. Co-creating knowledge fosters community. We reflect on how the autoethnography we are constructing together is different from other collaborative projects of which we have been a part. In this space, as woke womxn of color, we courageously and authentically show up and are vulnerable with one another. We let our brown hair down and breathe freely. This is a stark difference from other collaborations. Instead of the confidence and liberation we feel in the presence of other woke womxn, in past collaborations we have felt timid, insecure, and passive. We feared our contributions would not be fully valued. We realize that community is essential to survive in the academy. Bianca affirms this point when she writes, "To nurture our womxn of color community is to nurture our longevity and survival in the white man's castle." This poignant reflection exemplifies the necessity of community for woke womxn of color because although there are more of us in the academy, it is still not ours.

Shamika points out, "Having womxn of color around me feeds my soul in ways nothing else can; woke womxn of color get me and that is a relief." This reflection illustrates the impact community can have on woke womxn of color. Womxn of color in higher education cannot individually dismantle the systems that oppress us. In fact, when we acquiesce to the isolation inflicted upon us, we risk our wokeness, our sanity, and our survival. Instead, we must resist by coming together. Collectively, our presence changes the academy; it is when we are in community that we discover our shared strength. When in community, we create knowledge that would not otherwise be possible. This benefits us as woke womxn of color scholars and it benefits the academy with our contributions of new knowledge. Furthermore, being in community with other woke womxn of color is self-healing and liberating. We are able to share stories of defeat and triumph that unite us and help give us power that has been otherwise denied. By banning together as sista scholar familia, we dispel the false and oppressive rhetoric of scarcity, which suggests there is only room for one of us at the table. Through our wokeness and relationship together, we reject these lies and embrace one another as liberators. 


\section{Conclusion}

To be a womxn of color graduate student in higher education is an unquestionably isolating experience. To be a womxn and a person of color is to hold intersecting identities that are the antithesis of the ivory tower. As such, we and other womxn of color have been forced to occupy the margins of the academy. This double bind of racism and sexism has resulted in the methodical marginalization of our voices, the silencing of our perspectives, and the stifling of our brilliance (Hernandez, Ngunjiri, \& Chang, 2015). This not only pains us, but also suffocates and shackles the construction of new knowledge.

The origins of this collaboration were born out of necessity. Our so-called academic home, a rurally located, affluent, and predominantly white Midwest institution of higher learning, felt more like a prison. As woke womxn of color graduate students, we sought each other out for survival. What initially began as informal chats and checkins evolved into life-giving conversations of empathy, encouragement, and resilience. For our own wellness and wokeness, we banded together. By enduring the micro and macro-aggressions of living in the crosshairs of intersectional oppression, we formed a sista scholar familia. Being in relationship with one another may have started out of concern for our individual survival, but has grown into a shared desire to empower other womxn of color.

This is a movement. In writing this paper, we join our voices with the woke womxn of color sista scholar familia that has come before us: Andalzúa (1987), Crenshaw (1991), Collins (2000), hooks (1994), and Matias (2015) to name a few. Another voice in this movement, activist and organizer Grace Lee Boggs (1998) wrote:

Movements are not initiated by revolutionaries. They begin when large numbers of people, having reached the point where they can't take the way things are anymore, see some hope of improving their daily lives and begin to move on their own. (p. 210)

While womxn of color in higher education are not yet large in numbers, we have begun to move. This collaborative critical autoethnography is a rejection of the recycled isolation imposed upon us. By uniting as a sista scholar familia across racial lines, the co-authors of this paper embody what Boggs (1998) described as necessary to create a movement: "People of widely differing views and backgrounds need to come together around a vision" (p. 251). Our vision is to inspire and embolden other womxn of color graduate students in higher education. We write this paper as a declarative renunciation of the chains of misogyny, patriarchy, and racism that have for too long oppressed us.

In the words of inspiring woke womxn of color sista scholar and shero ${ }^{5}$, Dr. Cheryl Matias, "Then, I suddenly remembered why I entered academia-for the love, for the hope, the determination to change the pain of racism" $(2015$, p. 67). This is our vision, our goal, our calling-to change the pain of the intersectional oppression of racism and sexism that has plagued womxn of color in higher education since our arrival. We aspire to be the agents of awakening that enable other womxn of color in 
higher education to get woke. We acknowledge that there is a tense duality to wokeness, and yet we endure. We take comfort and courage in our community of woke sista scholars to stay woke in this journey. In the context of the cyclical rhetoric of isolation for womxn of color in academia, it takes strength and ferocity to come together. But when we do, when we find each other, speak to one another, and write together, our potential and power is astounding. We are WOKE.

\section{Notes}

1. The authors use "womxn" as a symbol of resistance to move beyond a monolithic, white-dominant, cisgender, man-centered understanding of "womxnhood" and move toward a more inclusive and empowered meaning.

2. The authors use "sista scholars" to refer to other woke womxn of color scholars.

3. The authors intentionally write "white" with a lowercase "w" as a form of resistance against the assumed dominance of white supremacy.

4. The authors use "hxrstories" to reject patriarchal domination. With this alternative spelling, we resist a tradition of our lives being written under a "his-story" of colonizing patriarchy. Hxrstories center our stories as womxn of color as a process of decolonization and liberation.

5. The authors use "shero" to denote a feminist female hero.

\section{References}

Arredondo, G. F., Hurtado, A., Klahn, N., Najera-Ramirez, O., \& Zavella, P. (Eds.). (2003). Chicana feminisms: A critical reader. Durham, NC: Duke University Press.

Anzaldúa, G. (1987). Borderlands = La frontera. San Francisco, CA: Aunt Lute Books.

Anzaldúa, G., \& Moraga, C. (1983) This bridge called my back: Writings by radical women of color. Latham, NY: Kitchen Table, Women of Color Press.

Baszile, D. T. (2011). The riot in my soul-part I: A critical rant on race, rage and the limits of formal education on these matters. In E. Malewski \& N. Jaramillo (Eds.). Epistemologies of ignorance in education (pp. 244-267). Charlotte, NC: Information Age Publishing.

Bhattacharya, H. (2008). New critical collaborative ethnography. In S. N., Hesse-Biber \& P. Leavy (Eds.), Handbook of emergent methods (pp. 303-324). New York, NY: Guilford. 
Boggs, G. L. (1998). Living for change: An autobiography. Minneapolis, MN: University of Minnesota Press.

Boylorn, R. M., \& Orbe, M. P. (2013). Critical autoethnography: Intersecting cultural identities in everyday life. New York, NY: Routledge.

Brookfield, S.D. (2005). The power of critical theory for adult learning and teaching. London, England, U.K.: Open University Press.

Chang, H., Ngunjiri, F., \& Hernandez, K.C. (2013). Collaborative autoethnography. Walnut, CA: Left Coast Press.

Chang, H. (2008). Autoethnography as method. New York, NY: Routledge.

Collins, P. H. (2000). Black feminist thought: Knowledge, consciousness, and the politics of empowerment. New York, NY: Routledge.

Crenshaw, K. W. (1991). Mapping the margins: Intersectionality, identity politics, and violence against women of color. Stanford Law Review, 43, 1241-1299.

Delgado, R., \& Stefancic, J. (2001). Critical race theory: An introduction. New York, NY: New York University Press.

Hernandez, K.C., Ngunjiri, F. W., \& Chang, H. (2015). Exploiting the margins in higher education: A collaborative autoethnography of three foreign-born female faculty of color. International Journal of Qualitative Studies in Education, 28(5), 533-551.

Hill, D. (2014). A vulnerable disclosure: Dangerous negotiations of race and identity in the classroom. Journal of Pedagogy, 5(2), 161-181.

hooks, b. (1994). Teaching to transgress: Education as the practice of freedom. New York, NY: Routledge.

Ladson-Billings, G. (1998). Just what is critical race theory and what's it doing in a nice field like education? International Journal of Qualitative Studies in Education,11(1), 7-24. doi: 10.1080/095183998236863

Loewenberg, B. J., \& Bogin, R. (1976). Black women in nineteenth-century American life: Their words, their thoughts, their feelings. University Park, PA: Penn State University Press.

Lorde, A. (1984). Sister outsider: Essays and speeches. Trumansburg, NY: Crossing Press.

Matias, C.E. (2015). "I ain't your doc student": The overwhelming presence of whiteness and pain at the academic neoplantation. In K. J. Fasching-Varner, K. A., Albert, R. W. Mitchell, \& C. M. Allen (Eds.). Racial battle fatigue in higher education: Exposing the myth of post-racial America. Lanham, MD: Rowman \& Littlefield.

Mohamed, T. (2010). Surviving the academy: The continuing struggle of minority faculty on mainstream campuses. The International Journal of Diversity in Organizations, Communities, and Nations, 10(4), 41-52. 
Nast, H. J. (1999). Sex, race, and multiculturalism: Critical consumption and the politics of course evaluations. Journal of Geography in Higher Education, 23(1), 102115.

Pittman, C. (2010). Race and gender oppression in the classroom: The experiences of women faculty of color with white male students. Teaching Sociology, 38(3), 183196.

Rich, A. (2002). Arts of the possible: Essays and conversations. New York, NY: W.W. Norton \& Company.

Souto-Manning, M., \& Ray, N. (2007). Beyond survival in the ivory tower: Black and brown women's living narratives. Equity \& Excellence in Education, 40(4), 280290.

Williams, M., Dunlap, M., \& McCandies, T. (1999). Keepin' it real: Three black woman educators discuss how we deal with student resistance to multicultural inclusion in the curriculum. Transformation, 10(2), 11-23.

\section{Author Contact}

Aeriel A. Ashlee: ashleeaa@miamioh.edu

Miami University, 210 E. Spring St., Oxford, OH 45056, USA

Bianca Zamora: zamorabt@miamioh.edu

Miami University, 210 E. Spring St., Oxford, OH 45056, USA

Shamika N. Karikari: johns263@miamioh.edu

Miami University, 210 E. Spring St., Oxford, OH 45056, USA 